\title{
EFL Students' Perspective on the Use of Quizizz as Online Learning Media During COVID-19 Pandemic
}

\author{
${ }^{*}$ N N Dewi ${ }^{1}$, I W Astuti ${ }^{1}$ \\ ${ }^{1}$ Department of English Language Education, Faculty of Psychology and Socio-Cultural Sciences, \\ Universitas Islam Indonesia, Yogyakarta, 55584, Indonesia
}

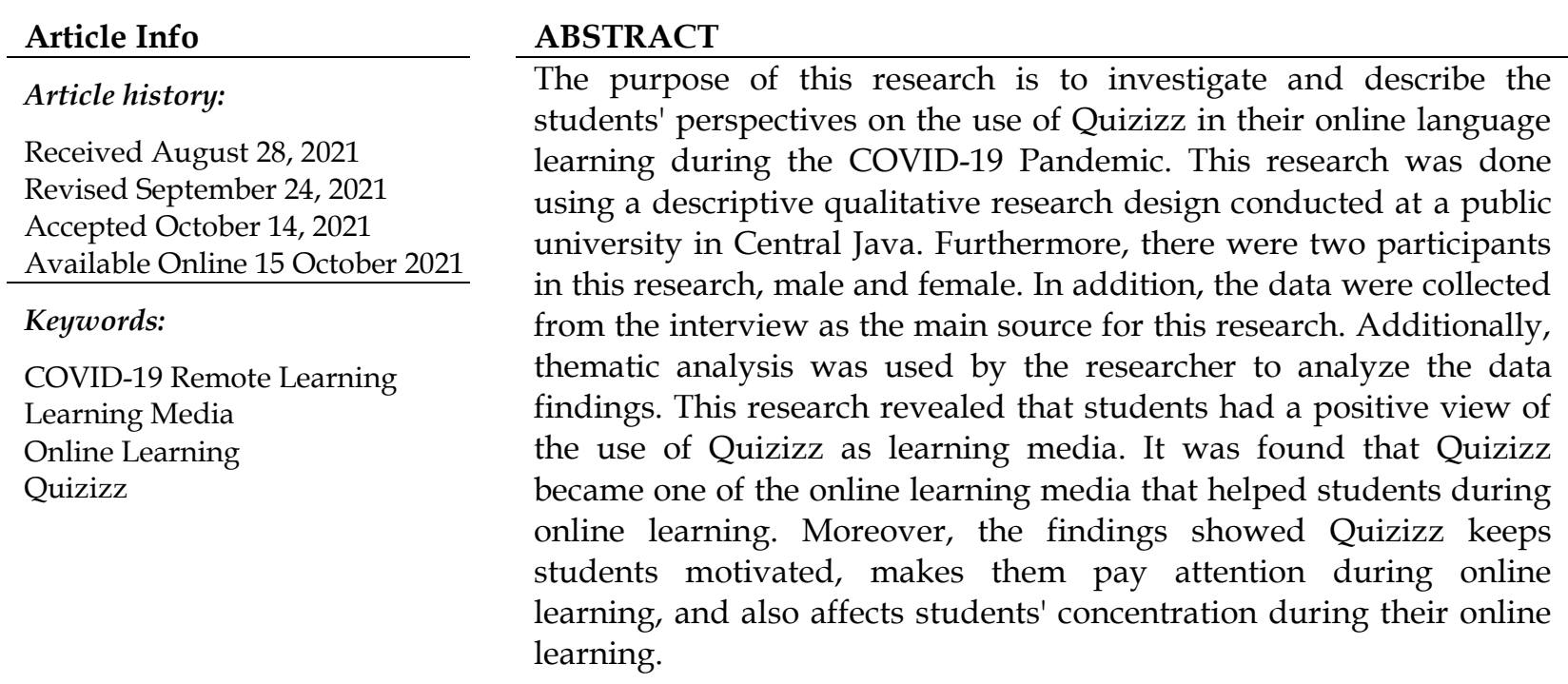

\section{INTRODUCTION}

The development of increasingly sophisticated technology is a means of achieving educational goals which require educators at any level of education to be able to use and innovate with more modern tools available in the world today. Many learning technologies nowadays can facilitate the teaching and learning processes, including the provision and the use of online learning media to help teachers improve learning both inside and outside the classroom or through distance learning (Muhammad, 2020). Learning media can be defined as assistance for teachers in providing materials to students to make learning more effective and efficient (Puspitarini \& Hanif, 2019). Meanwhile, online learning media can be interpreted as using internet-based educational aids to facilitate the teaching and learning process to achieve the learning goals (Mabruri \& Hamzah, 2020). In the context of foreign language learning, online learning media enables teachers and students to interact more freely and makes it easier for students to access what they need or be referred to as "student-centered". Many studies have shown how e-media motivates students to learn the language and has significantly improved their language skills as well by way of employing students' gadgets independently, and as a substitute for traditional learning (Muhammad, 2000). The study from Kaur \& Nadarajan (2020) concerning the use of Kahoot in language learning and teaching shows students' positive perception of and its benefit in helping them train their language learning skills, and how Kahoot increases their learning engagement during the teaching and learning process. This, among others, exemplifies the beneficial use of online learning media to help improve students' language learning skills. Additionally, web-based or online learning media such as Quizizz, Kahoot, Google Classroom, and Zoom can facilitate more effective delivery of the learning materials and can enhance students' involvement in the learning process. Although this type of 
learning may not occur face to face, web-based learning media present teachers with a variety of content, interface, and exciting methods to choose from.

With a reference to the present condition of the Covid-19 pandemic, not only have schools and educators been forced to teach online, but they have also been made to quickly adopt more fitting online media to facilitate learning in this troubled time. The limited infrastructure (lack of internet connection and electricity) has also forced many students to hike some hills from their villages to obtain internet signals and/or learning from their low-end mobile devices. One of the impacts of this situation is, unfortunately, decreased students' motivation due to the difficulties of understanding the material during this remote-online learning. In the light of such pressing demand and challenging conditions, technological acceleration for learning must be significantly increased during this pandemic. As stated by Famularsih (2020), replacing it with interactive online learning can boost up students' motivation in this difficult situation.

Ever since the pandemic hit and the remote-online learning has become the best resort for most schools and teachers, and also online learning is one of the best ways to carry out the teaching and learning process (Sunarto, 2021). Many researchers and educators have generated quite significant reflections and findings from their online classroom practice. One of the implementations of online learning during this current pandemic, for example, from Kumar et al. (2020) suggests that online learning with supportive software such as Google Classroom makes online learning more effective as it is quite accessible and convenient to use. Other than Google Classroom, Zoom is also massively used as online learning media during the pandemic. Tesar (2020) claimed that Zoom provides students' facilities in the learning process and boosts their engagement. From the Indonesian context, Zuhriyah \& Pratolo (2020) stated that the development of this online platform could be seen through many educational online platforms that have been used extensively for the tool as a learning medium, such as Kahoot, Socrative, Edmodo, and Quizizz. These online platforms can support the implementation of online-based learning which potentially helps students to learn more effectively while improving their learning experience.

Quizizz is one of the applications for online-based learning. Zhao (2019) stated that Quizizz is one of the game-based online educational tools, an interactive multiplayer online game-based platform, an easy to access platform for students, and an effective platform to save learning times. Quizizz has been used as a learning media during the language learning process in many educational places. It has been proven by many kinds of research on the implementation of Quizizz in language learning from various places. The First research is in a private university in Yogyakarta conducted by Zuhriyah and Pratolo (2020); the finding of this research showed that students believe Quizizz is a fun and attractive tool. Moreover, Quizizz can push their selfconfidence to make students more motivated and increase their ability to learn English. The data above proved that the students think Quizizz can motivate them to study a language. The second is conducted at English department students of Universitas Majalengka from Fakhruddin \& Nurhidayat (2020); the findings showed the students have a good perception of implementing Quizizz in learning. In the third study conducted by Amalia (2020) from Dynamic English Course, the findings are the students have a positive perspective on using Quizizz as a web appraisal instrument for English education and learning, especially on a formative assessment. The fourth research is in STKIP PGRI Trenggalek conducted by (Basuki \& Hidayati, 2019); the research found that the students think Quizizz is more effective than Kahoot with scores of 15.002 (Quizizz) and 12.248 (Kahoot!). The fifth, research conducted by Chaiyo \& Nokham (2017) from the faculty of nursing Chiang Rai college Thailand; this research showed that students' perception towards Quizizz is good and Kahoot is perceived positively by students. However, the results agree that Kahoot and Quizizz enhance the learning experience. The sixth is about the use of Quizizz in senior high school Majalengka, which uses Quizizz to assess the students' understanding of reading comprehension (Ratnasari et al., 2019). In sum, Quizizz can help the teachers to measure the students' understanding of the material. Besides, another function of Quizizz is to enhance the students' motivation to study language 
because it makes the learning process distressful. Last, the seventh study from Lestari (2019) conducted in STKIP PGRI Tulungagung shows that Quizizz makes students more motivated; it attracts students more to do the quizzes through Quizizz than Kahoot; it makes them more independent because they have no chance to cheat, and it increases their engagement. This indicates that Quizizz contributes to boosting up students' motivation and student engagement.

The setting of this research was in the English language education department class at one of the public universities in Central Java whose most of its English learning process during the COVID-19 pandemic took place using Quizizz. The students have experienced using Quizizz for eight meetings in one semester (4 meetings before midterm exams and four meetings before final exams). The learning tool was used by the lecturer to create exercises, conduct language learning tasks, and engage students in their English class.

\section{RESEARCH METHOD}

This research employed thematic analysis in which the data was generated and analyzed descriptively for its most trending and prominent themes. The data was primarily collected via in-depth, semi-structured interviews employing the participants' voice notes. The participants of this research were two EFL sophomores in one of the public universities in Central Java taking an English reading course at the English Department. These participants were selected via purposive sampling technique in which the participants must have known how to use Quizizz or had been using Quizizz at least 5 to 10 times and been taking/participating in an English course when this research was conducted.

\section{RESULTS AND DISCUSSION}

This section describes the findings of students' perspectives towards the use of Quizizz as online learning media during the COVID-19 pandemic. Several relevant works of literature also support these findings. In addition, the result of the participants' interviews was cited to substantiate the findings of the study.

The students' perspectives regarding the use of Quizizz as online learning media during COVID-19 Pandemic are as follows: (1) They claimed Quizizz as a helpful media during online learning, (2) It affects students' concentration, (3) It makes them comfortable, (4) It keeps students motivated, (5) It makes them pay attention during online learning. The researcher discusses the result for each category under the following subsections.

\section{Assisting Students in the Learning Process}

The use of Quizizz learning media was a common practice by one of the public universities in Central Java, even the use of those learning media was used for eight meetings in one semester during this outbreak. Furthermore, Quizizz learning media was applied by some lecturers for giving daily quizzes after the course hours were over.

This was done because some students would be more interested and enjoy learning English through Quizizz. Basuki \& Hidayati (2019) stated that Quizizz was a fun, engaging, and motivating app. In correlation with that theory, as mentioned by participants 1 (P1), he said that he was pleased when doing quizzes through Quizizz learning media because there were various exciting features, and does not feel boring when using Quizizz. Moreover, participants 2 (P2) explained that Quizizz was very suitable and effective to be applied within online learning during the COVID-19 pandemic caused by its features. The students usually used Quizizz by using a smartphone and directly accessing it from the lecturer's link via WhatsApp group.

"I think the use of Quizizz is one of the most interesting ways that teachers can apply. I personally prefer to do quizzes through Quizizz because there are many interesting and not boring features in Quizizz" (Participants 1) 
"I feel that Quizizz is very suitable and effective to apply in online learning during COVID-19 Pandemic and also the settings in Quizizz itself can be adjusted to the needs of students" (Participants 2)

Additionally, the students already had good views about the use of Quizizz during online learning caused by its features. Moreover, students perceived that Quizizz helped them during online learning. Based on P1, he said that Quizizz had helped him in various ways such as, add new vocabulary, get rid of boredom, increase his English comprehension, and also increase his creativity. This explanation is proven from the interviews. Below is the statement was given by $\mathrm{P} 1$ in the interview session.

"Quizizz helps get rid of that boredom with interesting features, doesn't feel boring, and it is different from the other apps. Quizizz can increase my enthusiasm of learning" (Participants 1)

"With the time limit feature on Quizizz, it helps me to improve accuracy and speed in English comprehension. With that limited time, I have to be able to understand what the questions are. This can certainly be a trigger for me to improve my English vocabulary. So, I can easily understand the meaning of each question presented" (Participants 1)

Similarly, P2 mentioned that Quizizz also helped her in various ways such as adding new vocabularies, helping minimize cheating in doing the test, and also helping her to understand the meaning in English.

\section{"Quizizz is really helpful, it can help to add new vocabulary" (Participants 2)}

"I think, Quizizz is very helpful during online learning because it is easy to use... other than that, Quizizz can minimize cheating in doing the test because the time settings are limited" (Participants 2)

To sum up the explanations above, the researcher can infer that students will be more interested in doing the quizzes through Quizizz because Quizizz was the most exciting way and suitable to apply during the COVID-19 pandemic. Quizizz was very helpful to facilitate students to improve their accuracy and speed in English comprehension, then Quizizz also helps get rid of boredom to increase their enthusiasm for learning. In correlation with that, Wibawa et al. (2019) explained that Quizizz provides real applicable forms to increase students' enthusiasm in learning so that they do not feel bored in learning. Quizizz also helps to minimize cheating in doing the test. It is also because Quizizz provides shuffled answers for each question. Hence, they keep focusing on their questions (Basuki \& Hidayati, 2019). In addition, Quizizz is an online quiz application that is very useful and can help students to improve their vocabulary (Juniarta et al., 2020). The reason was that the time limit features and also English language settings applied to the Quizizz. Thus, it requires them to understand the meaning or command in English, so it will automatically add to their vocabulary.

\section{Affecting Students' Concentration}

Concentration is one of the important aspects of the learning process. As mentioned by Paget (2010) as cited in Li \& Yang (2016) that concentration refers to an individual's effort to focus on whatever he or she is thinking about. In addition, according to the result of the interview, both EFL learners who participated in this research claimed that Quizizz improved their concentration in the learning process. In fact, concentrating on doing the quiz in Quizizz is very important. About the previous statement, P1 mentioned that concentration is needed in working on questions so that all questions can be answered perfectly. Furthermore, P2 
explained that Quizizz is very useful for focusing students' concentration. In line with Basuki \& Hidayati (2019), who explained that Quizizz makes students focus more on doing the quiz by not breaking the students' concentration during the quiz.

"With the limited time in working on the questions, Quizizz helped me to increase my concentration in doing the questions. Because I think the concentration in doing the questions in Quizizz is important. Because once my concentration disperses, I won't be able to solve all the questions perfectly. Through Quizizz, my concentration in learning was trained" (Participants 1 )

"I think, with Quizizz I was trained to always focus and concentrate, on each question provided because the time given is very limited. Therefore, Quizizz seems to require users to always focus, concentrate, and also think critically to remember the learning material that has been given accompanied by reading the questions, understanding the questions, and also finding the answer of the questions provided" (Participants 2)

"When I am careless, it can be sure that I will lose the opportunity to answer the questions and this affects the score that will be obtained at the end of the questions provided" (Participants 2)

As a result, from the explanation above, these two participants claimed that they were more concentrated when doing the questions because there was a time limit for each item on the Quizizz. Besides, it makes them have to stay focused on the questions provided, because once they let their guard down, they will lose their opportunity to answer the questions perfectly, and it will affect their rank and score. As mentioned by Dewi et al. (2020), due to the limited time availability, students will be excited and interested in answering the quiz, so they will feel challenged to answer every question. Consequently, it would force them to think critically. Additionally, Quizizz can be more effective in improving students' critical thinking skills compared to conventional learning. In correlation with that theory, Nashar et al. (2021) mentioned that using Quizizz, students' critical thinking skills will increase, and they will be more motivated. Besides, based on Zuhriyah \& Pratolo (2020), the skimming method is needed to help students read and answer the questions quickly according to the time set. Related to the theory, the interview result shows that students' concentration is tested with the students having to remember the material, read, understand, and answer the questions at the same time. Moreover, students are always required to focus. It can be concluded that those perspectives from the students show that Quizizz trains students' concentration during the learning process and concentration is the important thing because it will help students to get the perfect test score.

\section{Enhancing Students' Learning Comfort}

In this challenging situation, online learning is carried out to facilitate teaching and learning processes. However, during online learning, many students do not understand the learning materials if they do not meet their teacher directly. Consequently, the use of technology is needed to facilitate teaching and learning processes to be more effective (Dhawan, 2020). Therefore, through Quizizz, the teaching and learning process will run effectively. In addition, Wibawa et al. (2019) revealed that Quizizz is effective because it does not require paper and pen. Quizizz has an important role in the learning process, such as it can increase students' learning comfort during the learning process, because its features are not complicated, unlike the other apps. This is proven by the research from Zhao (2019) who revealed that Quizizz has special features such as memes, avatars, themes, and music that make students feel comfortable during the learning process. Moreover, according to the interview with the two participants in this research, the result shows that Quizizz makes them comfortable during the learning 
process. The reason was that Quizizz has interesting features, is not monotonous, and is not complicated to apply.

"It is comfortable because I use Quizizz through my smartphone because accessing via smartphone is simpler and more efficient. In addition, the features are very convenient to try because it is easy, interesting, and simple. Honestly, I don't like it when I use a website or service where accessing it takes a long time and is a complicated process. Well, but all the things I don't like are not in Quizizz" (Participants 1)

"I am very comfortable using Quizizz because there are various themes, features, and other supporting features and it's designed like playing a game, so it creates a strong sense of excitement, and this is also an added value than using a web or other application that tend to be monotonous. By using Quizizz I didn't get bored even the questions given" (Participants 2)

"I really like Quizizz because it is easy to use, fun, and I feel that I like learning while playing. So, I feel like I want to do it again and again" (Participants 2)

In summary, those perspectives from two different students explain how Quizizz makes them feel comfortable and can attract students' interest to do the test. Since the features which Quizizz has were not in other apps (Lestari, 2019). In addition, they also revealed that this comfortable aspect will increase their enthusiasm in the learning process during online learning. Furthermore, Wibawa et al. (2019) revealed that Quizizz was an application that can increase the students' enthusiasm for learning, also by using Quizizz the students do not feel bored in participating during online learning.

\section{Increasing Students' Motivation During Online Learning}

Motivation is an important aspect of the teaching and learning process, especially during online learning. Motivation also can be created by applying learning media. As mentioned by Puspitarini \& Hanif (2019) the use of learning media in the learning process will also have a positive impact on students to increase their learning motivation. Related to the theory, the result of the interview shows that the students had the same views which they mentioned that learning media such as Quizizz can encourage students' motivation during online learning. In addition, they mentioned that Quizizz is also an encouragement to study even harder.

"I think this is how Quizizz really made me realize that exercise does not always get boring. This makes me motivated to find various interesting ways to learn, such as using Quizizz. Quizizz also sparked my enthusiasm to compete healthily with a friend to get the highest score when working in the exercise" (Participants 1)

"I can say Quizizz is one of the reasons I keep learning and motivated to study even harder. Quizizz is a special encouragement for me to be even better to practice in the next exercise through Quizizz, when I get a mediocre rank or score, I want to be better, get a higher score, and more concentrate when working on the questions given for the next Quizizz" (Participants 2)

Meanwhile, to encourage student's motivation during online learning, learning media such as Quizizz can be applied due to Quizizz, students will not feel bored and the use of Quizizz as learning media can increase motivation in following lessons. Furthermore, working on practice questions through Quizizz makes students more motivated. In correlation with that, Zhao (2019) stated that Quizizz lets students compete to measure their abilities against each other. Due to rankings on Quizizz, students have high competitiveness against other students. With 
high motivation and competitiveness, students who still get mediocre ranks and scores will put in more effort to study harder to get better rankings and scores than before. In correlation with that, Sadirman (2012) as cited in Puspitarini \& Hanif (2019) who stated that taking the exercise will prepare students to get high scores in their studies. Consequently, it will also train their concentration in the learning process.

Based on the explanation above, learning media such as Quizizz really motivates students in learning due to competition between students to get the highest rank and score. Therefore, this is following Junior (2020), who stated that ranking in real-time, allows motivating students in learning, since the intense competition from among students. On the contrary, Zuhriyah \& Pratolo (2020) mentioned that one of the weaknesses of using Quizizz is that the length of the time in doing the quizzes will affect the ranking or score obtained, the longer the time in doing the quiz, the result obtained will be decreased.

In conclusion, since Quizizz has motivated students in their learning process during online learning, the students thought that Quizizz is one of the effective learning media to support remote learning and it is related to the explanation from Wibawa et al. (2019), who said Quizizz is an interactive quiz application that can increase the spirit of learning to be more effective.

"With Quizizz, learning will be more effective. Considering that there are various settings and features in Quizizz, but it is easy to understand Quizizz's advantages that other apps or web do not have. Therefore, Quizizz is considered very effective in online learning during the COVID-19 Pandemic" (Participants 2)

As a result, according to the explanation above, the researcher can conclude that the use of Quizizz is considered as one of the interesting media to increase students' motivation during online learning. In addition, students will be motivated to get the top rank and the highest score among the other students. Moreover, related to the effectiveness of using Quizizz in the learning process, the students believe that Quizizz helps them to complete assignments without feeling bored. As mentioned by Fakhruddin \& Nurhidayat (2020) the learning process by using Quizizz will be more effective and efficient, this happened because Quizizz combines learning and playing, also Quizizz provides easy to use features. In addition, students feel more motivated in learning, and also the students feel glad if online learning activities are carried out through Quizizz media.

\section{Increasing Students' Engagement}

According to the interview result from the two participants in this research, it shows that the learning process especially during remote learning by applying Quizizz media would increase students' engagement. This is in line with Mei et al. (2018) which claimed that students will be more interested and focused on the lessons because the teacher uses Quizizz in the teaching and learning process. Likewise, Quizizz had a good impact on students' engagement and learning outcomes (Zhao, 2019). The reason was with good engagement, would increase students' attention in the teaching and learning process during online learning. Therefore, the students perceive that Quizizz greatly increases their attention because there is a willingness from the students to understand the problem-solving system, they pay attention to the questions, they do not do other activities while finishing the questions, and their independence to do the test due to shuffle questions and answer (Lestari, 2019).

"Yes, Quizizz increases my attention and my learning engagement during online learning. Before getting to know Quizizz, I didn't pay much attention to the assignment... because I think the assignments given are boring. But when I found out about Quizizz, then my attention increased" (Participants 1) 
"It is really fun like I feel using Quizizz is different from other media. I mean, with simple, unique, and easy to understand features, Quizizz has become one of my favorite learning media" (Participants 1 )

"Quizizz greatly increases attention and learning engagement for me during online learning. This is because there is only limited time to complete the Questions practice so that whether you want it or not, students must always be on standby to the questions that have been provided. When you are careless, you will lose the opportunity to answer the questions" (Participants 2)

"I am really excited. I really like Quizizz because it is easy to use, fun, and I feel like learning while playing. So, I feel that I want to do it again and again. I think Quizizz is very suitable as a learning media" (Participants 2 )

As a result, the researcher can conclude that students' attention has a very influential aspect in learning through Quizizz. The findings of this research have proven that Quizizz really brings fun to the class. This current research finding was also similar to the research conducted by Lestari (2019) in which they also found that Quizizz has a good impact on increasing students' engagement. In addition, the students also have a positive response toward the use of Quizizz such as a feeling of excitement, and the feeling to repeat the test again and again and it is related to the explanation from Basuki \& Hidayati (2019) who said that Quizizz brings extraordinary progress, Quizizz is interesting, addictive, and motivates for students to learn and achieve the learning goals, also using Quizizz feels like playing a game because it is interesting and fun (Amalia, 2020). This is due to the interesting characteristics of its features. In correlation with that, Zhao (2019) stated that Quizizz is very helpful because it is easy to use, making doing-in class exercises is more fun and the features on Quizizz encourage their interest in learning.

\section{CONCLUSION}

This research shows that each student has a different view related to the use of Quizizz. However, generally in this research, both of the students have claimed that Quizizz has been very helpful for them during online learning. Both students perceive Quizizz as having a positive impact on their learning process. Quizizz helps and facilitates them during online learning in terms of enriching their vocabulary knowledge, increasing their enthusiasm in learning, and helping to dispose of boredom. Quizizz also increases the students' learning motivation during online learning. The use of Quizizz is also reported to affect their comfortability during the learning process. Such comfort has led students to be more excited, curious, and feeling pleased to participate in the learning activities, and this is especially true with their reference to Quizizz's interesting features.

\section{ACKNOWLEDGEMENT}

Thanks to two EFL sophomores in one of the public universities in Central Java who have participated in this research. Special thanks to the editorial team and reviewer of SiLeT Journal who has provided many suggestions for this manuscript.

\section{REFERENCES}

Amalia, D. F. (2020). Quizizz website as an online assessment for English teaching and learning: Students' perspectives. Jo-ELT (Journal of English Language Teaching) Fakultas Pendidikan Bahasa E Seni Prodi Pendidikan Bahasa Inggris IKIP, 7(1), 1-8. https://doi.org/10.33394/joelt.v7i1.2638

Basuki, Y., \& Hidayati, Y. (2019). Kahoot! or Quizizz: The students' perspectives. ELLIC, 1-10. https:// doi.org/10.4108/eai.27-4-2019.2285331 
Chaiyo, Y., \& Nokham, R. (2017). The effect of Kahoot, Quizizz and Google forms on the student's perception in the classrooms response system. IEEE, 1-5. https://getkahoot.com/how-it-works

Dewi, K. S., Myartawan, I. P. N. W., Swari, N. K. T. A., \& Sugihartini, N. (2020). Quizizz effect on students' grammar mastery in higher EFL classroom based mobile assisted language learning (MALL). Language and Education Journal UNIDKSHA, 3(1), 15-24. https:// doi.org/http://dx.doi.org/10.23887/leju.v3i1.24589

Dhawan, S. (2020). Online learning: A panacea in the time of COVID-19 crisis. Journal of Educational Technology Systems, 49(1), 1-18. https:// doi.org/10.1177/0047239520934018

Fakhruddin, A., \& Nurhidayat, E. (2020). Students' perception on Quizizz as game based learning in learning grammar in written discourse. Wiralodra English Journal, 4(2), 28-38. https:// doi.org/10.31943/wej.v4i2.101

Famularsih, S. (2020). Students' experiences in using online learning applications due to COVID-19 in English classroom. Studies in Learning and Teaching, 1(2), 112-121. https:// doi.org/10.46627/silet

Juniarta, P. A. K., Dewi, K. S., Mahendrayana, G., \& Swandana, I. W. (2020). The Analysis on the Implementation of Mobile-Assisted Language Learning Strategy Through Quizizz Application to Improve Student's Reading Comprehension at Undiksha Singaraja. 3rd International Conference on Innovative Research Across Disciplines, 323-327. https:// doi.org/10.2991/assehr.k.200115.053

Junior, J. B. (2020). Assessment for learning with mobile apps: Exploring the potential of Quizizz in the educational context. International Journal of Development Research, 10(1), 33366-33371. http://www.journalijdr.com/assessment-learning-mobile-apps-exploringpotential-quizizz-educational-context

Kaur, P., \& Nadarajan, R. (2020). Language learning and teaching using Kahoot! International Journal of Modern Education, 2(5), 19-28. https:// doi.org/10.35631/ijmoe.25003

Kumar, J. A., Bervell, B., \& Osman, S. (2020). Google Classroom: Insights from Malaysian higher education students' and instructors' experiences. Education and Information Technologies, 25(5), 1-21. https://doi.org/10.1007/s10639-020-10163-x

Lestari, T. W. (2019). Kahoot! and Quizizz: A comparative study on the implementation of Elearning application toward students' motivation. Journal of English Language Teaching $\begin{array}{llll}\text { Learning } \quad \text { Literature, 13-22. } & \text { 2(2), }\end{array}$ https://journal.stkippgritrenggalek.ac.id/index.php/kid/article/view/150

Li, X., \& Yang, X. (2016). Effects of learning styles and interest on concentration and achievement of students in mobile learning. Journal of Educational Computing Research, 54(7), 1-24. https:// doi.org/10.1177/0735633116639953

Mabruri, \& Hamzah. (2020). The urgency of using internet-based arabic learning media in online learning in the global pandemic era. Loghat Arabi: Jurnal Bahasa Arab \& Pendidikan Bahasa Arab, 1(2), 1-10. https:// doi.org/10.36915/la.v1i2.13

Mei Suo Y, Ju Suo Y, \& Adam Zalika. (2018). Implementing Quizizz as game based learning in the arabic classroom. European Journal of Social Sciences Education and Research, 12(1), 208212. https://doi.org/10.26417/ejser.v12i1.p208-212

Muhammad. (2020). Promoting students "Autonomy through online learning media in EFL class. International Journal of Higher Education, 9(4), 320-331. https:// doi.org/10.5430/ijhe.v9n4p320

Nashar, Nurhasanah, A., \& Fauzan, R. (2021). The effectiveness of critical thinking ability on the basis of Quizizz application viewed from problem based learning model in history learning of senior high school. IOP Conference Series: Earth and Environmental Science, 747(1), 1-8. https:// doi.org/10.1088/1755-1315/747/1/012046

Puspitarini, Y. D., \& Hanif, M. (2019). Using learning media to increase learning motivation in elementary school. Anatolian Journal of Education, 4(2), 53-60. https:// doi.org/10.29333/aje.2019.426a 
Ratnasari, E., Hikmawati, R., \& Ghifari, R. N. (2019). Quizizz application as gamification platform to bridge students in teaching reading comprehension. Seminar Nasional Pendidikan,

https:// prosiding.unma.ac.id/index.php/semnasfkip/article/view/195

Sadirman A.M. (2012). Teaching and learning interaction \& motivation. Rajawali Pers.

Sunarto, M. (2021). Change unplanned into planned online learning: An effort to follow health protocols at an information technology college during the covid-19 pandemic period. Studies in Learning and Teaching, 2(1), 16-28. https://doi.org/10.46627/silet.v2i1.62

Tesar, M. (2020). Towards a post-covid-19 'new normality?': Physical and social distancing, the move to online and higher education. Policy Futures in Education, 18(5), 556-559. https:// doi.org/10.1177/1478210320935671

Wibawa, R. P., Astuti, R. I., \& Pangestu, B. A. (2019). Smartphone-based application "Quizizz" as a learning media. Dinamika Pendidikan, 14(2), 244-253. https:// doi.org/10.15294/dp.v14i2.23359

Zhao, F. (2019). Using Quizizz to integrate fun multiplayer activity in the accounting classroom. International Journal of Higher Education, 8(1), 37-43. https://doi.org/10.5430/ijhe.v8n1p37

Zuhriyah, S., \& Pratolo, B. W. (2020). Exploring students' views in the use of Quizizz as an assessment tool in English as a foreign language (EFL) class. Universal Journal of Educational Research, 8(11), 5312-5317. https://doi.org/10.13189/ujer.2020.081132

\section{Author (s):}

*Naomi Nirwasita Dewi

Department of English Education, Faculty of Psychology and Socio-Cultural Sciences

Universitas Islam Indonesia,

Jl. Kaliurang, Yogyakarta 55584, Indonesia

Email: 17322046@students.uii.ac.id

Irma Windy Astuti

Department of English Education, Faculty of Psychology and Socio-Cultural Sciences

Universitas Islam Indonesia,

Jl. Kaliurang, Yogyakarta 55584, Indonesia

Email: 062216005@uii.ac.id 